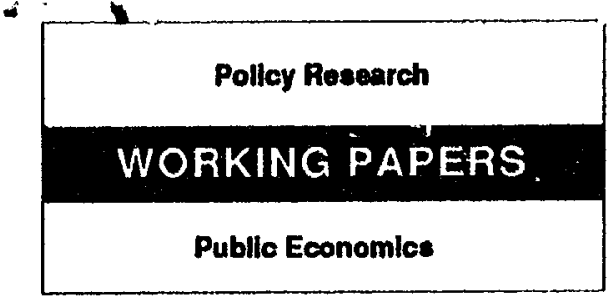

Policy Research Department

The World Bank

September 1993

WPS 1178

\title{
Productivity of Public Spending, \\ Sectoral Allocation Choices, and Economic Growth
}

\author{
John Baffes \\ and \\ Anwar Shah
}

The model results suggest that reshaping public spending priorities in favor of human resource development and away from military spending would positively stimulate world economic renewal. 


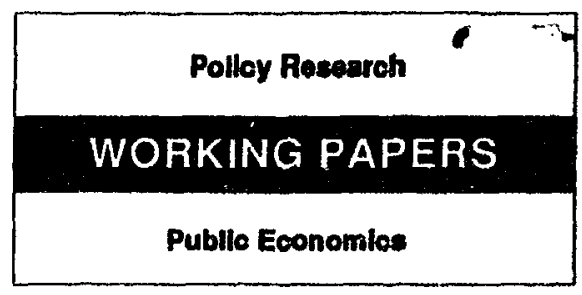

WPS 1178

This paper - a product of the Public Economics Division, Policy Research Department- was presented at the 1993 Annual Meetings of the American Economic Association in Anaheim, Califomia, in January 1993. Copies of the paper are available free from the World Bank, 18i3 H Street NW, Washington, DC 20433. Please contact Carlina Jones, room Ni0-063, extension 37699 (September 1993, 15 pages).

Baffes and Shah examine the composition of public spending and its implications for economic growth.

They use a translog production function by treating gross domestic product as the output and labor, private capital, and several types of public sector capital siocks as the inputs, using timeseries data for 25 countries for 1965-84.

Thi production functions of all but four countries exhibited increasing returns to scale. The highest output elasticity was for human resource development capital, followed by private capital and labor. Output elasticity of infrastructure capical was found to be relatively small, with the exception of Latin American countries where it exhibited relatively high values. Militar r capital had negative output elasticity in slightly more than half of the cases considered.

The results suggest that reshaping public spending priorities in favor of human resource development and away from military spending would positively ,timulate world economic renewal.

The Policy Research Working Paper Series disseminates the findings of work under way in the Bank. An objective of the series is to get these findings out quickly, even if presentations are less than fully polished. The findings, interpretations, and conclusions in these papers do not necessaril:' represent official Bank policy. 


\title{
PRODUCTIVITY OF PUBLIC SPENDING, SECTORAL ALLOCATION CHOICES
} AND ECONOMIC GROWTH

\author{
Jokn Baffes and Anwar Shah \\ The World Bank
}

This paper was presented at the 1993 Annual Meetings of the American Economic Association, Anaheim, California, January 5-8, 1993. The authors are grateful to the session participants (David Canning, Michael Dietch, Charles Hulten, Dale Jorgenson, Ishaq Nadiri and Robert Schwab) for comments, and to Costas Christou for substantial input. They would also like to thank Lawrence Summers for inspiration for this paper and Nancy Birdsall, Sadiq Ahmed, Gobind Nankani, Javad Khalilzadeh-Shirazi, William McCleary, Antonio Estache, Vikram Nehru. Michael Stevens, Shanta Devarajan, Vinaya Swaroop and Min Zhu for comments.

Please address correspondence to: Anwar Shah, Principal Economist, Public Economics Division, Policy Research Department, The World Bank, Room N10-053, 1818 H Street, N.W., Washington, D.C. 20433. Tel:(202)473-7687, FAX:(202)676-0025 


\section{PRODUCTIVTY OF PUBLIC SPENDING, SECTORAL ALLOCATION CHOICES AND ECONOMIC GROWTH}

\section{INTRODUCTION}

Government deficits especially in developing and emerging market economies have been rising at an alarming pace in recent years. Some countries have responded to this fiscal crisis by reducing public spending on infrastructure and human resource development. At the present time, policymakers dj not appear to have access to any empirical evidence on the sectoral allocation of public investment and its implications for economic growth. Such evidence, as pointed out by Summers $(1991,1992)$ is vital in making tough choices on public spending priorities. In the absence of this empirical guidance, Summers suggested that in the developing world at least a prima facie case can be made to protect public investment in critically deficient aspects of infrastructure and female education.

According to :ecent advances in endogenous growth theory, factors contributing to the crors-country differences in both the level of per capita income and the growth rates are: investment in human capital (Lucas, 1988), knowledge spillovers (Romer, 1989), and investment in physical capital and infrastructure (DeLong and Summers, 1990; Murphy et al., 1989).

Looking at the microeconomic aspect of those issues, a number of recent studies have reflected on the productivity of public spending on infrastructure (see e.g. Aschauer, 1989; U.S. Congress, 1991; Shah, 1988, 1992; Berndt and Hansson, 1992; Richards, 1992; Lynde and Richmond, 1993). However, sectoral allocation of public investment (i.e. on infrastructure, human resource development capital, defense capital, etc) and its implications for economic growth remains largely an unexplored area of research.

This paper takes an important first step in the above direction. Specifically, it employs a flexible production structure methodology where various public and private inputs interact and contribute to national output. Public capital is disaggregated into infrastructure, human resource development and military capital stocks. Based on an analysis of time-series (1965-84) and cross-section (25 countries) data, the paper concludes tr * public investment in human resource development provides a stimulus for economic growth, whereas the contribution of military spending to economic growth appears to be negative for a substantial number of countries. 
Thus, the paper finds some empirical support for the development strategy that argues for curtailment of public spending on defense and higher spending on education training and heaith.

The rest of the paper is organized as follows. Section 2 provides a description of the empirical framework within which the estimation procedures will be carried out, while section 3 describes the data used. Section 4 presents and discusses the econometric results. Finally, a concluding section addresses the policy implications of results.

\section{MODEL SPECIFICATION AND ESTIMATION}

The Solow-type models (Solow, 1957) postulate that a country's output can be represented by a well-behaved aggregate production relationship of the following form:

$$
Q=f(K ; t)
$$

where $Q$ denotes a measure of aggregate output, $\boldsymbol{K}$ is a vector referring to measures of different types of inputs used in the production process (typically laoor and physical capital), while $t$ represents time and is supposed to capture technical change. With a few exceptions, relationship (I) is approximated by a Cobb-Douglas type of technology. ${ }^{1}$

In response to the limited class of variables included in $K$, another body of literature has emerged. This body of literature uses cross-country regressions in order to detect linkages between growth rates and a variety of economic indicators. ${ }^{2}$ The ubvious advantage of the latter class of models is the flexibility of including a variety of explanatory variables. However, the structure of this (linear) formulation does not allow one to detect any substitutability or complementarity conditions among factors of production that might be present.

In order to account for the inflexibility of Cobb-Douglas function and at the same time take into account the fact that factors of production may be substitutes or complements with one another, relationship (1) is approximated by the following translog specification (Christensen et al, 1973):

$$
\ln Q=\alpha_{0}+\sum_{i=1}^{n} \alpha_{i} \ln K_{l}+(1 / 2) \sum_{i=1}^{n} \sum_{j=1}^{n} \alpha_{i} \ln K_{l} \ln K_{j}+\gamma t+u_{l}
$$


where $u_{t}$ is an error term assumed to possess all classical statistical properies, while $\alpha_{0}, \alpha_{i}, \alpha_{i j}$ and $\gamma$ denote parameters to be estimated, with $\alpha_{i j}=c_{j i}$; one can impose constant returns to scale in (2) by restricting the parameters as follows: $\Sigma_{i} \alpha_{i}-l=\Sigma_{i} \alpha_{i j}=0, \forall i, j$. However, since one of the major objectives of this study is to test rather than assume such a structure, we considered the unrestricted version of the model.

Differentiation of (2) with respect to input $i$ gives the marginal product of input $i$, which expressed in elasticity form defines the output elasticity with respect to input $i$ :

$$
\epsilon_{i}=\frac{\partial \ln Q}{\partial \ln K_{i}}-\alpha_{i}+\sum_{j=1}^{n} \alpha_{i j} \ln K_{j} .
$$

Note that the $\epsilon_{i}$ defined above can be viewed as a unit free measure of the relative contribution of capital input $i$ to the overall output and its interpretation is straightforward: How much the output is going to change if the use of input $i$ changes by one percentage unit? Furthermore, based on the estimates of the $\epsilon_{i}$, one can calculate the elasticity of scale as: $\epsilon=\Sigma_{i} \epsilon_{i}{ }^{3}$ Values of scale elasticity exceeding unity are consistent with increasing returns to scale; conversely, values of $\epsilon$ less than urity are consistent with decreasing returns to scale.

As a measure of output we have taken per capita Gross Domestic Product (GDP). We have considered five types of capital stocks. These include labor, private capital, infrastructure capital, human resource development capital and military capital, and again divided by the population in order to come up with the per canita figures for the inputs. It is important to note that the human resource development capital, in a sense, captures different quality levels of labor that might exist among countries or even within the same country at different time periods. That, in other words, corresponds to the skill and experience augmented notion of labor or the corcept of effective labo: (Lucas, 1988).

Before we proceeded with the estimation, some preliminary tests were performed in order to further invest. ${ }_{i}$ ate the nature of the employed technology. As mentioned earlier, one of the justifications and innovations of this study is the introduction of a flexible production structure. Therefore, a reasonable point of departure was to test the hypothesis of whether the above production specification is consistent with the Cobb-Douglas technology. In terms of the parameters defined in (2) such a test requires that all the $\alpha_{i j}$ s (i.e., the cross-terms coetricients) 
be zero. $F$-statistics uniformly rejected a Cobb-Douglas specification for the production function in favo: of a translog form for all five regions and th arefore pointing to the conclusion that a flexible specification is more appropriate than a Cobb-Douglas one.

The second set of tests involved the question of whether the employed production function is homogenous of degree one, or stated otherwise whether the technology is characterized by constant returns to scale. Such a hypothesis was tested by imposing the restriction: $\Sigma_{i} \alpha_{i}-1=\Sigma_{i} \alpha_{i j}=0 . \forall i, j$. This hypothesis was also rejected, at the $5 \%$ level of significance, for all five regions considered, suggesting that the employed technology is not characterized by constant returns to scale.

Ordinary least squares was utilized in order to estimate the above translog specification. Because it is likely that there exist many differences among the countries considered within each regional group, two types of dummies corresponding to each country were introduced in each equation. An intercept dummy to capture differences in levels (level effects) and a time trend dummy to capture differences in the slope (slope effects) were used.

\section{DATA DESCRIPTION}

Our sample covers the $1965-84$ period and includes a total of 25 countries from different regions of the world, characterized by a wide range of income levels. Although it would have been desirable to apply the translog specification on a country by country basis, because of degrees of freedom limitations we pooled the data and considered regressions by region and income level rather than by country.

The countries of our sample are divided among five regions as follows: (1) AFRICA: Egypt, Kenya, Tanzania, and Zimbabw';; (2) ASIA: Indonesia, India, Pakistan, Korea, Sri Lanka, Malaysia, Philippines, and Thailand; (3) EMENA: Greece, Iran, Israel, Portugal, and Turkey; (4) LAT: Bolivia, Colombia, Mexico, and Venezuela; (5) OECD: Canada, Japan, U.S.A., and Germany. The description of the variables used in the analysis is as follows:

GDP: Gross Domestic Product was obtained from the IMF, International Financial Statistics database aid was teflated by the GDP deflator and divided by population in order to express it in per $c_{c} \cdot$ : ta terms. 
Labor: Data on manhours worked were obtained from the International Labour Office, Yearbook of Labour Statistics (various issues) and from unpublished World Bank data sources.

Private Capital Stocks: Series wer iunstructed using the perpetual inventory method from published and unpublished data on private investment in the U.N. System of National Accounts. A depreciation rate of $10 \%$ was assumed.

Infrastructure Capital Stocks: Series were constructed from the IMF, Government Finance S.-tistics (various issues) and U.N. System of National Accounts (various years). The perpetual inventory method was used with a depreciation rate of $5 \%$.

Human Resource Development Capital Stock: Series were constructed using the perpetual inventory method and assuming a $10 \%$ depreciation rate, from relevant public investment series on health, education and training obtained from IMF, Government Finance Statistics (various issues) and the U.N. System of National Ac:ounts (various years) ${ }^{4}$.

Military Capital Stock: Series were constructed from the IMF, Government Finance Statistics (various issues) and the U.N. System of National Accounts (various years). The perpetual inventory method was used with a depreciation rate of $10 \%$.

\section{RESULTS}

Table 1 reports parameter estimates consistent with specification (2). To conserve space we do not report parameter estimates associated with country specific intercept and time trend dummies. It is important to note that the signs of the parameter estimates do not have a direct interpretation for our purposes. However, most of the coefficients are significant at the $5 \%$ level of significance; further, looking at the $R^{2}$ s and the $F$-values (bottom of Table 1), one can conclude that the model performed in a quite satisfactory manner. ror example, with the exception of the $L A T$ region, which had an adjusted $R^{2}$ of 0.97 , all other adjusted $R^{2} s$ were 0.99 . At the same time, all $F$-statistics were significant at the $1 \%$ level of significance. ${ }^{5}$

The first five columns of table $2 \mathrm{~A}$ report elasticity estimates for the five types of capital stocks (i.e. labor, private capital, infrastructure capital, human resource development capital and military capital), evaluated at the sample means. Furthermore, the last column of the same table presents the scale elasticities for each of the sample countries. Table 2B reports the same class of results based on a different classification scheme. Specifically, we have classified the 
countries of our sample according to their 1996 per capit: GDP (ranked from the lowest to the highest). ${ }^{6}$

The overall conclusions drawn from Tables $2 \mathrm{~A}$ and $2 \mathrm{~B}$ can be summarized as follows. In most countries scale elasticities exceeded unity, thus pointing to the conclusion that the economies considered exhivit increasing returns to sale. Four notable exceptions were Canada, Israel, Pakistan, and Zimbabwe. Private capitai and human resource development capital seemed to be the major determinants of GDP; labor stocks were the third, in terms of importance; infrastructure capital exhibited low output elasticity; and finally, military capital had negative output elasticities in many instances.

As already noted, Table 2B reports the same elastivities as Table $2 \mathrm{~A}$, but with the countries classified in a different scheme. In particular, the countries have been ordered from the ones with the lowesi to the ones with the highest per capita GDP. Such an ordering scheme was motivated by the desire to identify possible consistent patterns between the stage of economic development (approximated by the level of per capita GDP), and the relative contribution of the each of the different factors of production.

First consider the scale elasticities. On the average, medium income countries exhibited higher scale elasticity than low income countries (1.23 versus 1.05 respectively). Furthermore, medium to high income countries exhivited higher scale elasticities than medium income countries. High income countries exhibited the same level of scale elasticities as the medium to high income ones (if one excludes Israel). One, therefore, would tend to conclude that higher per capita GDP is consistent with higher scale elasticities.

The elasticity of labor stocks in the low income countries averaged 0.15 while for the medium income it averaged 0.17 . For medium to high and high income they averaged 0.23 and 0.44 respectively. One can observe a clear pattern here: As per capital GDP rises, the relative contribution of l:bor increases as well. The overall contribution of labor however, with the exception of high income countries, was lower than the one of private capital as well as the one of human resource development capital.

We now turn to the private capital stocks. The average output elasticity with respect to private capital for the low income group was $\mathbf{0 . 2 7}$, while for the other groups it was very much comparable (it averaged to 0.37 ). In terms of overall performance, with the exception of high 
income countries, private capital ranked second after human resource development capital, in terms of its contribution in output growth.

The third capital stock used in the analysis is infrastructure. As mentioned earlier, the output elasticities of infrastructure capital were found to be relatively low. The only geographic region which exhibited relativcly high output elasticity is the $L A T$ region (it avernged 0.15 ). All other regions exhibited elasticities of this type of capital lower than 0.05 . It is important to mention that the output elasticity of infrastructure estimates presented here are not directly comparable to the ones obtained by Aschauer (1989), Munnell (1990) and Shah $(1988,1992)$, since all those studies estimate output elasticities of infrastructure considering private output rather than national output. The output elasticities of infrastructure using private output are generally expected to be higher than the ones using national output (GDP).

Human resource development capital showed the highest ol tput elasticity comparec to all other types of capital stocks. For the low income countries, the average output elasticity of human resource development capital was $\mathbf{0 . 5 8}$, twice as much compared to the one of the private capital stocks. The same result holds for the medium income countries for which the average human resource development capital elasticity with respect to output equals $\mathrm{J} .65$, almost twice its private capital counterpart. However, for the high income countries, the human resource development capital elasticity of output was lower than the elasticity with respect to labor and similar to the one wiih respect to private capital. Furthermore, the human resource development capital elasticity of output for the high income coun ries was the lowest among all four groups.

The last type of stock considered was military capital. In 13 countries the output elasticity of military capital turned out to be negative. ${ }^{7}$ With the exception of Tanzania, in all low income countries the military capital exhibited a negative output elasticity. On the other hand, with the exception of Venezuela, the medium to high income countries were characterized by positive elasticities. The other two groups presented rather mixed results.

\section{CONCLUSIONS AND POLICY IMPLICATIONS}

The objective of this paper was to examine the relationship between the different components of public investment and the rate of economic growit. A translog production model was estimated, by expressing per capita GDP as a function of the following five types of capital 
stocks: labor, private capital, infrastructure capital, human resource development capital, and military capital. From a sample of 25 countries which covers the 1965-84 time period, with the exception of four cases, the production functions of ail countries exhibited increasing returns to scale. The highest output elasticity was with respect to human resource development capital followed by private capital and labor. Infrastructure capita! exhibited low outpat elasticity, while military capital had negative output elasticity in slightly more than half of the cases considered.

This suggests that reshaping public eypenditure priorities in favor of human resource development capital and away from miliary spending will provide a positive stimulus for the growth of the world economy. 


\section{ENDNOTES}

1. A relatively large body of literature has utilized Cobb-Douglas specification in growth accounting models e.g. Aschauer (1989), Antle (1983), Thomas and Wang (1992).

2. For a survey of models using linear regressions of growth on economic indicators see Levine and Renelt (1992). They also examine the sensitivity of these models regarding the particular selection of explanatory variables. Also, for the relationship between growth and technical change see Hulten (1992). For some empirical work on the subject see Devarajan et al., 1993 and Landau, 1993 on the economic impact of military expenditures.

3. Note that the definition of returns to scale is $\epsilon=\partial \ln f(\lambda K) /\left.\partial \ln \lambda\right|_{\lambda=1}$, where $\mathbf{K}$ denotes the input vector (McElroy, 1969). The definition introduced in the text is used for computational purposes.

4. Only capital spending data are utilized.

5. One should note here that the LAT region had the least satisfactory performance among the five regions considered as the t-statistics indicate.

6. We have used the ICP measure of GDP which is based on the United Nations International Comparison program (World Development Report, 1992).

7. The output elasticities with respect to inputs are unit free measures of the marginal products which are expected to be positive in order for the production function to be well behaved. Therefore, the finding of negative elasticity of ourput with respect i military capital contradicts the assumption the production function is well behaved. 
TABLE 1: Translog Production Function Parameter Estimates

\begin{tabular}{|c|c|c|c|c|c|}
\hline & AFKICA & $A S I A$ & EMENA & $O E C D$ & $L A T$ \\
\hline $\ln \left(K_{1}\right)$ & $\begin{array}{c}-1.403 \\
(-0.27)\end{array}$ & $\begin{array}{l}-1.755 \\
(-1.66)\end{array}$ & $\begin{array}{r}8.482 \\
(4.45)\end{array}$ & $\begin{array}{l}-16.17 \\
(-3.47)\end{array}$ & $\begin{array}{c}5.604 \\
(0.41)\end{array}$ \\
\hline $\ln \left(K_{2}\right)$ & $\begin{array}{c}-0.352 \\
(-0.23)\end{array}$ & $\begin{array}{r}2.468 \\
(3.24)\end{array}$ & $\begin{array}{c}5.283 \\
(2.64)\end{array}$ & $\begin{array}{r}7.070 \\
(4.46)\end{array}$ & $\begin{array}{l}-1.532 \\
(-0.46)\end{array}$ \\
\hline $\ln \left(K_{3}\right)$ & $\begin{array}{l}-0.889 \\
(-2.09)\end{array}$ & $\begin{array}{r}0.152 \\
(0.78)\end{array}$ & $\begin{array}{l}-2.687 \\
(-4.01)\end{array}$ & $\begin{array}{c}3.099 \\
(2.73)\end{array}$ & $\begin{array}{r}2.101 \\
(1.63)\end{array}$ \\
\hline $\ln \left(K_{4}\right)$ & $\begin{array}{r}2.295 \\
(1.10)\end{array}$ & $\begin{array}{r}0.342 \\
(0.39)\end{array}$ & $\begin{array}{r}6.308 \\
(3.28)\end{array}$ & $\begin{array}{c}-1.423 \\
(-0.82)\end{array}$ & $\begin{array}{l}-6.911 \\
(-0.66)\end{array}$ \\
\hline $\ln \left(K_{5}\right)$ & $\begin{array}{c}2.744 \\
(1.55)\end{array}$ & $\begin{array}{l}-1.935 \\
(-2.22)\end{array}$ & $\begin{array}{c}-2.262 \\
(-1.68)\end{array}$ & $\begin{array}{r}7.219 \\
(2.52)\end{array}$ & $\begin{array}{c}5.680 \\
(0.75)\end{array}$ \\
\hline $\ln \left(K_{1}\right) \ln \left(K_{l}\right)$ & $\begin{array}{c}-0.088 \\
(-0.31)\end{array}$ & $\begin{array}{r}0.255 \\
(5.51)\end{array}$ & $\begin{array}{l}-0.375 \\
(-3.32)\end{array}$ & $\begin{array}{l}-0.966 \\
(-1.89)\end{array}$ & $\begin{array}{c}-0.579 \\
(-0.59)\end{array}$ \\
\hline $\ln \left(K_{1}\right) \ln \left(K_{2}\right)$ & $\begin{array}{c}0.739 \\
(5.39)\end{array}$ & $\begin{array}{l}-0.112 \\
(-2.06)\end{array}$ & $\begin{array}{r}0.440 \\
(1.90)\end{array}$ & $\begin{array}{c}1.104 \\
(2.68)\end{array}$ & $\begin{array}{r}1.280 \\
(1.83)\end{array}$ \\
\hline $\ln \left(K_{1}\right) \ln \left(K_{3}\right)$ & $\begin{array}{c}0.029 \\
(0.51)\end{array}$ & $\begin{array}{l}-0.025 \\
(-1.96)\end{array}$ & $\begin{array}{l}-0.197 \\
(-2.97)\end{array}$ & $\begin{array}{r}0.387 \\
(2.48)\end{array}$ & $\begin{array}{r}0.020 \\
(0.14)\end{array}$ \\
\hline $\ln \left(K_{l}\right) \ln \left(K_{4}\right)$ & $\begin{array}{l}-0.181 \\
(-0.47)\end{array}$ & $\begin{array}{c}-0.133 \\
(-1.35)\end{array}$ & $\begin{array}{l}-0.649 \\
(-2.94)\end{array}$ & $\begin{array}{c}0.154 \\
(0.59)\end{array}$ & $\begin{array}{l}-1.451 \\
(-1.29)\end{array}$ \\
\hline $\ln \left(K_{1}\right) \ln \left(K_{5}\right)$ & $\begin{array}{l}-0.22 S \\
(-1.10)\end{array}$ & $\begin{array}{c}0.284 \\
(3.01)\end{array}$ & $\begin{array}{r}0.100 \\
(1.10)\end{array}$ & $\begin{array}{c}-0.119 \\
(-0.38)\end{array}$ & $\begin{array}{c}0.163 \\
(0.20)\end{array}$ \\
\hline $\ln \left(K_{2}\right) \ln \left(K_{2}\right)$ & $\begin{array}{c}-0.642 \\
(-0.31)\end{array}$ & $\begin{array}{c}-0.194 \\
(-3.08)\end{array}$ & $\begin{array}{c}-1.159 \\
(-3.12)\end{array}$ & $\begin{array}{l}-0.315 \\
(-2.71)\end{array}$ & $\begin{array}{l}-0.539 \\
(-1.85)\end{array}$ \\
\hline $\ln \left(K_{2}\right) \ln \left(K_{3}\right)$ & $\begin{array}{c}-0.241 \\
(-1.14)\end{array}$ & $\begin{array}{c}-0.012 \\
(-0.46)\end{array}$ & $\begin{array}{c}1.272 \\
(5.83)\end{array}$ & $\begin{array}{l}-0.215 \\
(-2.55)\end{array}$ & $\begin{array}{c}-0.571 \\
(-2.38)\end{array}$ \\
\hline $\ln \left(K_{2}\right) \ln \left(K_{4}\right)$ & $\begin{array}{r}1.302 \\
(2.66)\end{array}$ & $\begin{array}{c}0.186 \\
(3.14)\end{array}$ & $\begin{array}{c}0.428 \\
(0.84)\end{array}$ & $\begin{array}{c}0.160 \\
(1.16)\end{array}$ & $\begin{array}{r}1.263 \\
(1.70)\end{array}$ \\
\hline $\ln \left(K_{2}\right) \ln \left(K_{5}\right)$ & $\begin{array}{l}-0.699 \\
(-3.67)\end{array}$ & $\begin{array}{l}-0.043 \\
(-0.91)\end{array}$ & $\begin{array}{c}0.401 \\
(1.13)\end{array}$ & $\begin{array}{l}-0.098 \\
(-0.45)\end{array}$ & $\begin{array}{r}0.126 \\
(0.43)\end{array}$ \\
\hline
\end{tabular}

cortinued 
TABLE 1: Translog Production Function Parameter Estimates (continued)

\begin{tabular}{lccccc}
\hline & $A F R I C A$ & $A S I A$ & $E M E N A$ & OECD & $L A T$ \\
\hline $\ln \left(K_{3}\right) \ln \left(K_{S_{3}}\right)$ & -0.065 & -0.001 & -0.582 & -0.012 & 0.296 \\
& $(-1.98)$ & $(-0.07)$ & $(-4.13)$ & $(-0.63)$ & $(3.62)$ \\
$\ln \left(K_{3}\right) \ln \left(K_{4}\right)$ & 0.374 & 0.009 & -0.581 & -0.047 & -0.091 \\
& $(1.59)$ & $(0.26)$ & $(-5.00)$ & $(-1.84)$ & $(-0.62)$ \\
$\ln \left(K_{3}\right) \ln \left(K_{s}\right)$ & 0.215 & 0.001 & -0.493 & -0.184 & -0.398 \\
& $(2.07)$ & $(0.01)$ & $(-4.93)$ & $(-2.16)$ & $(-2.62)$ \\
$\ln \left(K_{4}\right) \ln \left(K_{4}\right)$ & -1.030 & -0.166 & -0.279 & 0.032 & 0.276 \\
& $(-3.24)$ & $(-3.51)$ & $(-1.17)$ & $(0.41)$ & $(0.64)$ \\
$\ln \left(K_{4}\right) \ln \left(K_{5}\right)$ & 0.373 & 0.151 & 0.437 & -0.183 & -0.374 \\
& $(1.58)$ & $(2.64)$ & $(2.17)$ & $(-1.07)$ & $(-0.63)$ \\
$\ln \left(K_{5}\right) \ln \left(K_{5}\right)$ & 0.146 & -0.021 & -0.238 & 0.044 & 0.045 \\
& $(2.16)$ & $(-0.50)$ & $(-2.48)$ & $(0.45)$ & $(0.25)$ \\
$\mathrm{R}^{2}$ & 0.99 & 0.99 & 0.99 & 0.99 & 0.97 \\
F-value & 767.6 & 2723.9 & 6262.4 & 16239.4 & 114.8 \\
OBS & 80 & 160 & 100 & 80 & 80 \\
\hline
\end{tabular}

NOTES: The numbers in parentheses denote $t$-statistics. $K_{i}$ denotes the $i^{\text {th }}$ capital stock: $1=$ labor; 2 = private capital; 3 = infrastructure capital; 4 = human resource development capital; and $5=$ military capital. As noted in the text, all models contain intercept and time trend dummies which are suppressed here. The countries included in each of the regions are reported in the Appendix. OBS denotes the number of observations. $R^{2}$ is the adjusted $\mathbf{R}^{2}$. 
Table 2A: Output and Scale Elasticities: Countries Arranged By Geographic Region

OUTPUT ELASTICITIES WITH RESPECT TO

\begin{tabular}{lcclll}
\hline LABOR & PRIVATE & INFRASTRUCTURE & HUMAN RESOURCE & MILITARY & SCALE \\
& CAPITAL & CAPITAL & DEVEL. CAPITAL & CAPITAL & ELASTICITY \\
\hline
\end{tabular}

AFRICA

\begin{tabular}{lllllll}
\hline Egypt & 0.12 & 0.33 & 0.03 & 0.75 & -0.04 & 1.19 \\
Kenya & 0.15 & 0.22 & 0.04 & 0.85 & -0.01 & 1.25 \\
Tanzania & 0.09 & 0.25 & 0.02 & 0.70 & 0.01 & 1.07 \\
Zimbabwe & 0.10 & 0.25 & 0.02 & 0.56 & -0.03 & 0.90 \\
\hline ASIA & & & & & & \\
\hline Indonesia & 0.33 & 0.45 & 0.03 & 0.94 & -0.13 & 1.62 \\
India & 0.30 & 0.35 & 0.02 & 0.57 & -0.14 & 1.10 \\
Korea & 0.40 & 0.30 & 0.01 & 0.86 & 0.15 & 1.72 \\
Sri Lanka & 0.11 & 0.30 & 0.01 & 0.38 & 0.25 & 1.05 \\
Malaysia & 0.12 & 0.38 & 0.01 & 0.61 & 0.09 & 1.21 \\
Philippines & 0.20 & 0.30 & 0.01 & 0.60 & 0.04 & 1.15 \\
Thailand & 0.15 & 0.30 & 0.01 & 0.65 & 0.07 & 1.18 \\
Pakistan & 0.10 & 0.28 & 0.01 & 0.59 & -0.02 & 0.96 \\
\hline EMENA & & & & & & \\
\hline Greece & 0.17 & 0.52 & 0.05 & 0.54 & 0.04 & 1.32 \\
Iran & 0.15 & 0.57 & 0.04 & 0.49 & 0.03 & 1.28 \\
Israel & 0.29 & 0.17 & 0.05 & 0.15 & 0.02 & 0.68 \\
Portugal & 0.16 & 0.47 & 0.02 & 0.45 & 0.09 & 1.19 \\
Turkey & 0.16 & 0.57 & 0.03 & 0.41 & 0.03 & 1.20 \\
\hline OECD & & & & & & \\
\hline Canada & 0.16 & 0.39 & 0.02 & 0.30 & 0.07 & 0.94 \\
Japan & 0.73 & 0.39 & 0.01 & 0.49 & -0.01 & 1.61 \\
U.S.A. & 0.54 & 0.52 & 0.02 & 0.47 & -0.09 & 1.46 \\
Germany & 0.46 & 0.44 & 0.02 & 0.41 & -0.03 & 1.30 \\
\hline LAT & & & & & & \\
\hline Bolivia & 0.17 & 0.26 & 0.15 & 0.46 & -0.01 & 1.03 \\
Colombia & 0.08 & 0.27 & 0.16 & 0.71 & -0.08 & 1.14 \\
Mexico & 0.18 & 0.19 & 0.14 & 0.66 & -0.03 & 1.14 \\
Venezuela & 0.18 & 0.24 & 0.13 & 0.52 & -0.01 & 1.07 \\
\hline & & & & & & \\
& & & & & & \\
\end{tabular}

NOTES: The measures of elasticities have been calculated at sample means. 
Table 2B: Output and Scale Elasticities -- Countries Arranged By 1990 per Capita GDP (ICP Estimates)

OUTPUT ELASTICITIES WITH RESPECT TO

\begin{tabular}{lccccc}
\hline LABOR & PRIVATE & INFRASTRUCTURE & HUMAN RESOURCE & MILITARY & SCALE \\
& CAPITAL & CAPITAL & DEVEL. CAPITAL & CAPITAL & ELASTICITY \\
\hline
\end{tabular}

PANEL A: Low Income

\begin{tabular}{lllllll}
\hline Tanzania & 0.09 & 0.25 & 0.02 & 0.70 & 0.01 & 1.07 \\
Kenya & 0.15 & 0.22 & 0.04 & 0.85 & -0.01 & 1.25 \\
India & 0.30 & 0.35 & 0.02 & 0.57 & -0.14 & 1.10 \\
Pakistan & 0.10 & 0.28 & 0.01 & 0.59 & -0.02 & 0.96 \\
Bolivia & 0.17 & 0.26 & 0.15 & 0.46 & -0.01 & 1.03 \\
Zimbabwe & 0.10 & 0.25 & 0.02 & 0.56 & -0.03 & 0.90 \\
\hline \multicolumn{7}{l}{ PANEL B: } \\
\hline \multicolumn{7}{l}{ Medium Income } \\
Philippines & 0.20 & 0.30 & 0.01 & 0.60 & 0.04 & 1.15 \\
Indonesia & 0.33 & 0.45 & 0.03 & 0.94 & -0.13 & 1.62 \\
Sri Lanka & 0.11 & 0.30 & 0.01 & 0.38 & 0.25 & 1.05 \\
Egypt & 0.12 & 0.33 & 0.03 & 0.75 & -0.04 & 1.19 \\
Iran & 0.15 & 0.57 & 0.04 & 0.49 & 0.03 & 1.28 \\
Thailand & 0.15 & 0.30 & 0.01 & 0.65 & 0.07 & 1.18 \\
Colombia & 0.08 & 0.27 & 0.16 & 0.71 & -0.08 & 1.14 \\
Turkey & 0.16 & 0.57 & 0.03 & 0.41 & 0.03 & 1.20 \\
Malaysia & 0.12 & 0.38 & 0.01 & 0.61 & 0.09 & 1.21 \\
Mexico & 0.18 & 0.19 & 0.14 & 0.66 & -0.03 & 1.14 \\
\hline
\end{tabular}

PANEL C: Medium to High Income

\begin{tabular}{lllllll}
\hline Venezuela & 0.18 & 0.24 & 0.13 & 0.52 & -0.01 & 1.07 \\
Korea & 0.40 & 0.30 & 0.01 & 0.86 & 0.15 & 1.72 \\
Greece & 0.17 & 0.52 & 0.05 & 0.54 & 0.04 & 1.32 \\
Portugal & 0.16 & 0.47 & 0.02 & 0.45 & 0.09 & 1.19 \\
\hline
\end{tabular}

PANEL D: High Income

\begin{tabular}{lllllrl}
\hline Israel & 0.29 & 0.17 & 0.05 & 0.15 & 0.02 & 0.68 \\
Germany & 0.46 & 0.44 & 0.02 & 0.41 & -0.03 & 1.30 \\
Japan & 0.73 & 0.39 & 0.01 & 0.49 & -0.01 & 1.61 \\
Canada & 0.16 & 0.39 & 0.02 & 0.30 & 0.07 & 0.94 \\
U.S.A. & 0.54 & 0.52 & 0.02 & 0.47 & -0.09 & 1.46 \\
\hline
\end{tabular}

NOTES: The per capita GDP range is defined as: low is less than \$US 3,000; medium is between \$US 3,000 and 6,000; medium high is between \$US 6,000 and 9,000; and high is greater than \$US 9,000. The ICP measure of GDP is based on the United Nations International Comparison program estimates. 


\section{REFERENCES}

Antle, J. "Infrastructure and Aggregate Agricultural Productivity: International Evidence." Economic Development and Cultural Change, (1983):609-619.

Aschauer, D. "Is Government Spending Productive?" Journal of Monetary Economics, 23(1989):177-200.

Berndt, E.R. and B. Hansson. "Measuring the Contribution of Public Infrastructure Capital in Sweden." Scandinavian Journal of Economics, v.94(1992):151-168.

Christensen, L.R., D.W. Jorgenson, and L.J. Lau. "Transcendental Logarithmic Production Frontiers." Review of Economics and Statistics, 55(1973):28-45.

DeLong, B. and L. Summers. "Equipment Investment, Relative Prices and Economic Growth", mimeo, Harvard University, 1990.

Devarajan, S., V. Swaroop and H. Zou. "What Do Governments Buy?", Policy Research Working Papers, The World Bank, WPS 1082, 1993.

Hulten, C. "Growth Accounting When Technical Change is Embodied in Capital." American Economic Review, 82(1992):964-980.

Landau, D. "The Economic Impact of Military Expenditures". The World Bank Working Ppaer Series N0. 1138, May 1993.

Levine, R. and D. Renelt. "A sensitivity Analysis of Cross-Country Growth Regressions." American Economic Review, 82(1992):942-963.

Lucas, R. "On the Mechanics of Economic Development", Journal of Monetary Economics, XXI, pp. 3-42, 1988.

Lynde, C and J. Richmond. "Public Capital and Total Factor Productivity", International Economic Review, 34(1993),401-414.

McElroy, F.W. "Returns to Scale, Euler's Theorem and the Form of Production Functions." Econometrica, 37(1969):275-279.

Munnell, A. "Why Has Productivity Growth Declined? Productivity and Public Investment." New England Economic Review, Federal Reserve Bank of Boston, January/February, 1990, 3-22.

Murphy, K., A. Shleifer and R. Vishny "Industrialization and the Big Push", Journāl of Political Economy, v.97:5, pp. 103-126, 1989.

Richards, G.R. "Endogenous Technological Advance and Postwar Economic Growth: A Production Function Analysis", Eastern Economic Journal, v.18(1992): 315-332. 
Shah, A. "Dynamics of Public Infrastructure, Industrial Productivity and Profitability." Review of Economics and Statistics, 74(1992):28-36.

Shah, A. "Public Infrastructure and Private Sector Profitability and Productivity in Mexico." World Bank Policy, Planning and Research Working Paper No. 100, September, 1988.

Solow, R. "Technical Change and the Aggregate Production Function." Review of Economics and Statistics. 24(1957):312-320.

Summers, L.H. Keynote Address: Knowledge For Effective Action. Proceedings of the World Bank Annual Conference on Development Economics, World Bank, Washington, D.C., pp. 7-14.

Summers, L.H. "Keynote Address: Educating Girls." Proceedings of the 1992 Annual Conference of the Pakistan Society of Levelopment Economists, Islamabad, Pakistan.

Thomas, V. and Y. Wang. "Government Policies and Productivity Growth: Is East Asia an Exception?" mimeo, The World Bank, 1992.

U.S. Congress, Congressional Budget Office. How Federal Spending for Infrastructure and Other Public Investments Affects Economy. Washington, D.C. July 1991.

World Development Report. The World Bank, Oxford University Press, 1991. 


\section{Polloy Roeearch Working Paper Sorles}

\begin{tabular}{|c|c|c|c|c|}
\hline & Title & Author & Dato & $\begin{array}{l}\text { Contact } \\
\text { for paper }\end{array}$ \\
\hline WPS1164 & $\begin{array}{l}\text { Power, Distortions, Revolt, and } \\
\text { Reform in Agricultural Land Relations }\end{array}$ & $\begin{array}{l}\text { Hans P. Binswanger } \\
\text { Klaus Deininger } \\
\text { Gorshon Foder }\end{array}$ & July 1993 & $\begin{array}{l}\text { H. Binswanger } \\
31871\end{array}$ \\
\hline WPS1165 & $\begin{array}{l}\text { Social Costs of the Transition to } \\
\text { Capitalism: Poland, } 1 \neq 90-91\end{array}$ & Branko Milanovic & August 1983 & $\begin{array}{l}\text { P. Martin } \\
39026\end{array}$ \\
\hline WPS1166 & $\begin{array}{l}\text { The Behavior of Russian Firms in } \\
\text { 1992: Evidence from a Survoy }\end{array}$ & $\begin{array}{l}\text { Simon Commander } \\
\text { Leonid Liberman } \\
\text { Cecilia Ugaz } \\
\text { Ruslan Yemisov }\end{array}$ & August 1993 & $\begin{array}{l}\text { O. dol Cid } \\
35195\end{array}$ \\
\hline WPS1167 & $\begin{array}{l}\text { Unemployment and Labor Market } \\
\text { Dynamics in Russia }\end{array}$ & $\begin{array}{l}\text { Simon Commander } \\
\text { Leonid Liberman } \\
\text { Ruslan Yemtsov }\end{array}$ & August 1993 & $\begin{array}{l}\text { O. dol Cid } \\
35195\end{array}$ \\
\hline WPS1168 & $\begin{array}{l}\text { How Macroeconomic Projections } \\
\text { in Policy Framework Papers for the } \\
\text { Africa Region Compare with Outcomes }\end{array}$ & Rashid Faruqoe & August 1993 & $\begin{array}{l}\text { N. Tannan } \\
\mathbf{3 4 5 8 1}\end{array}$ \\
\hline WPS1169 & $\begin{array}{l}\text { Costs and Benefits of Debt and } \\
\text { Debt Service Reduction }\end{array}$ & Eduardo Fernandez-Arias & August 1993 & $\begin{array}{l}\text { R. Vo } \\
33722\end{array}$ \\
\hline WPS1170 & $\begin{array}{l}\text { Job Search by Employed Workers: } \\
\text { The Effects of Restrictions }\end{array}$ & $\begin{array}{l}\text { Avner Bar-llan } \\
\text { Anat Levy }\end{array}$ & August 1993 & $\begin{array}{l}\text { D. Ballantyne } \\
37947\end{array}$ \\
\hline WPS1171 & $\begin{array}{l}\text { Finance and lis Reform: Beyond } \\
\text { Laissez-Faire }\end{array}$ & $\begin{array}{l}\text { Gerard Caprio, Jr. } \\
\text { Lawrence H. Summers }\end{array}$ & Alugust 1993 & $\begin{array}{l}\text { P. Sintim- } \\
\text { Aboagye } \\
38526\end{array}$ \\
\hline WPS1172 & $\begin{array}{l}\text { Liberalizing Indian Agriculture: } \\
\text { An Agenda for Reform }\end{array}$ & $\begin{array}{l}\text { Garry Pursell } \\
\text { Ashok Gulatl }\end{array}$ & September 1993 & $\begin{array}{l}\text { D. Ballantyne } \\
\mathbf{3 7 9 4 7}\end{array}$ \\
\hline WPS1173 & $\begin{array}{l}\text { Morocco's Free Trade Agreement with } \\
\text { the European Community: } \\
\text { A Quantitative Assessment }\end{array}$ & $\begin{array}{l}\text { Thomas F. Rutherford } \\
\text { E. E. Putstrom } \\
\text { David Tarr }\end{array}$ & September 1993 & $\begin{array}{l}\text { N. Artis } \\
38010\end{array}$ \\
\hline WPS1174 & $\begin{array}{l}\text { Asian Trade Barriers Against Primary } \\
\text { and Processed Commodities }\end{array}$ & $\begin{array}{l}\text { Raed Safadi } \\
\text { Aloxander Yoats }\end{array}$ & September 1993 & $\begin{array}{l}\text { J. Jacobson } \\
33710\end{array}$ \\
\hline WPS1175 & $\begin{array}{l}\text { OECD Trade Barriers Faced by the } \\
\text { Successor States of the Soviet } \\
\text { Union }\end{array}$ & $\begin{array}{l}\text { Bartlomiej Kaminski } \\
\text { Aloxandor Yoats }\end{array}$ & September 1993 & $\begin{array}{l}\text { J. Jacobson } \\
33710\end{array}$ \\
\hline WPS1 176 & $\begin{array}{l}\text { Cash Social Transfers, Direct Taxes, } \\
\text { and Income Distribution in Late } \\
\text { Socialism }\end{array}$ & Branko Milanovic & September 1993 & $\begin{array}{l}\text { R. Martin } \\
39065\end{array}$ \\
\hline WPS1177 & $\begin{array}{l}\text { Environmental Taxes and Policles } \\
\text { for Developing Countries }\end{array}$ & $\begin{array}{l}\text { Neil Bruce } \\
\text { Gregory M. Ellis }\end{array}$ & September 1993 & $\begin{array}{l}\text { C. Jones } \\
37699\end{array}$ \\
\hline
\end{tabular}




\section{Policy Research Working Papor Sorles}

Titlo

WPS1178 Productivity of Public Spending. Soctoral Allocation Choices, and Economic Growth

WPS1179 How the Market Transition Affected Export Pertormance in the Central European Economies
Author

John Baffes

Anwar Shah

Dato

September 1993

Bartlomioj Kaminski

Septomber 1993
. Jones

37699

P. Kokila

33716

Contact

or papar 